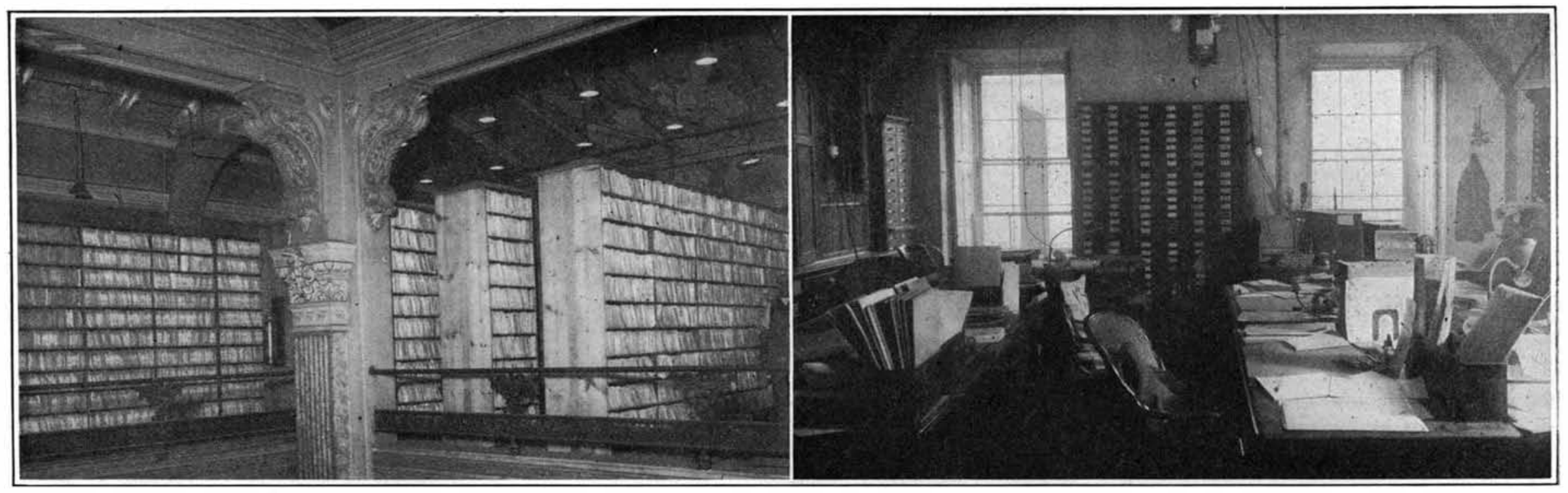

Left: A corner of the Patent Office, showing how thousands upon thousands of documents are filed away for reference purposes. Right: An examiner's room in the Patent Office. It is interesting to note that in 1836 the Patent Office became an independent bureau, headed by a commissioner, assisted by one examiner and six other subordinate clerks and employees

Two glimpses inside the United States Patent Office

\title{
Seventy-Five Years of American Patent Administration
}

How the System Has Developed from Small Beginnings, and What It Means to the Nation's Industry

By William I. Wyman

$S^{\text {EVENTY-FIVE years ago the leading industrial }}$ $S$ country was England. It was in that country that the Industrial Revolution began, due to a series of remarkable inventions of the most fundamental character which originated at about the time of the American Revolution. The inventions by Britishers of the spinning jenny, power loom, reverboratory puddling furnace and steam-engine-all perfected within half a generation-led immediately to the greatest of all changes in civilized history.

The Industrial Revolution and Human Nature The Industrial Revolution did everything but change human nature. It radically altered politics and history, and did a great deal to modify the appearance of old Mother Earth herself. England, the scene of this revolution, was its first beneficiary, and threequarters of a century ago its predominance in industry, commerce and wealth was uncontested. The United States was just feeling its way then in manufacturing and machine production. But in the infancy of its industrial life this country presented a radically new system of patent procedure and protection, which tended powerfully to stimulate ingenuity and advance the United States to the foremost place in invention and manufacture. England originated the patent system, her inventions which caused the Industrial Revolution gave strength and body to the system and in turn made it the occasion for the development and in turn made the United States act of 1836, deof the new era. The United States act of 1836, devised by Senator John Ruggles of Maine, constituting the so-called American method of granting patents, was the first vital departure from English patent laws. This act instituted the present organization of the United States Fatent Onifricas and in that short time demonstrated its virtues and possibilities.

The law it superseded and the prevailing procedure in all other industrial countries were based upon the "registration" system of granting patents without scrutiny of operaout scrutiny of operanovelty or demonstration of invention Except as it was made more effective by minur changes, the act of 1836 remains in larger outlines in the law of today ; and except for alterations which shall more effectively carry out its purpose and principles, it will persist in the systems of the future. While the

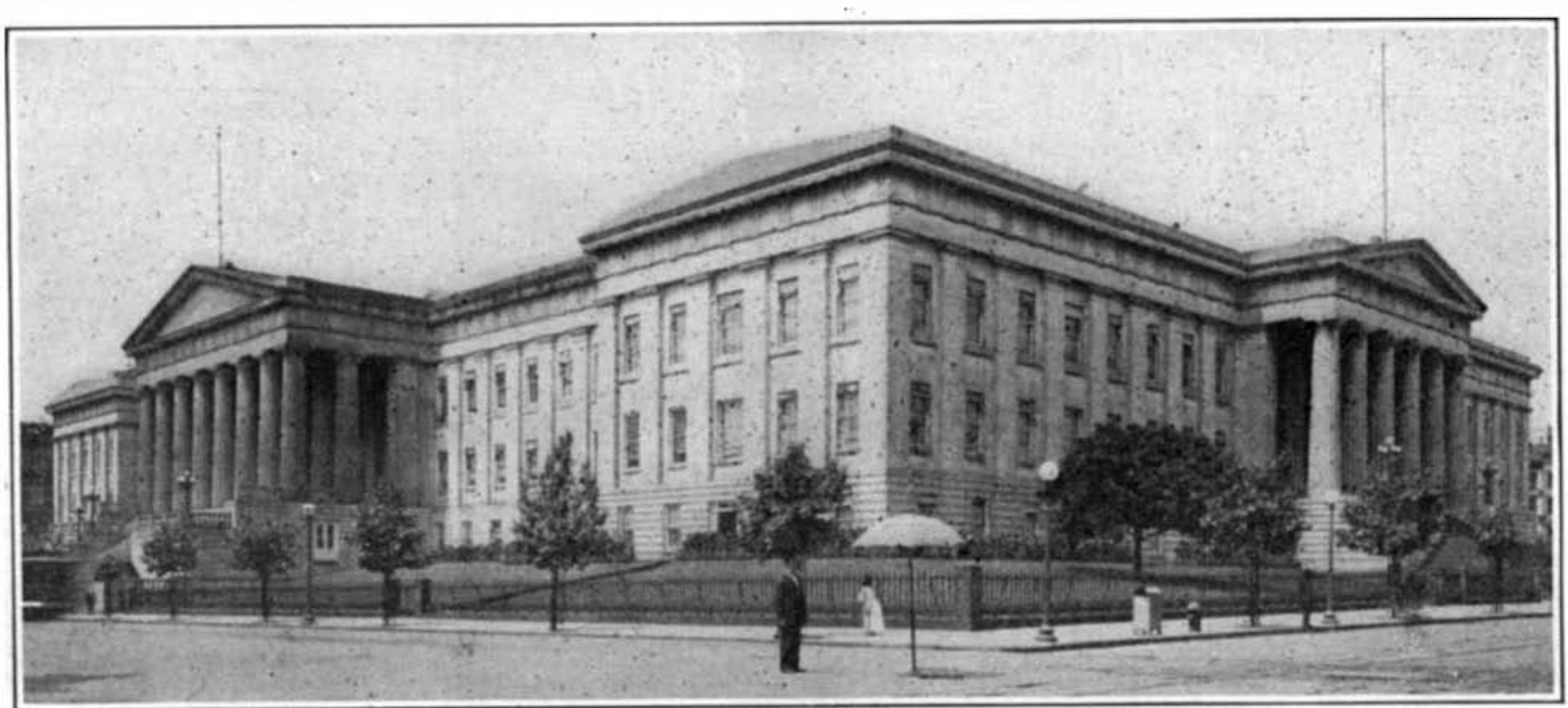

The Patent Office Building, the erection of which was begun in 1836 and finished in 1840 . This original structure forms the $F$ Street wing of the present building race by the newer industrial nations and she was compelled to alter her system in accordance with the methods which were conferring ascendency upon her competitors.

\section{Property in Ideas}

For the first time in all history the means for ascertaining and decreeing rights of property in ideas and promoting the objects of a system of patent protection was placed on an intelligent, scientific and adequate basis. Before this time, it was true that some measure of examination prior to the grant was indulged in. In Massachusetts and Connecticut, long before the Revolutionary War, patents were granted by the legislative bodies after a conference with the inventor and a scrutiny of the invention, while under the act of 1790 the Federal Government did the best it could to ascertain utility and the state of the art, but the efforts in these various directions to give valid basis for the patent were spasmodic and fragmentary. No facilities, organization or body of adequate law was ever provided before this time properly to initiate and carry on the "examination" system. This act provided a means for collecting the art, a personnel sufficiently trained to examine the same intelligently, and the machinery and procedure for scientifically endeavoring to give effect to the purpose of the law. That purpose was to throw on the Office the burden which the courts had alone performed, to determine the utility, novelty and patentability of the invention when and where the patent is granted, and, as one writer puts it, "To eliminate litigation 'before it begins.'

The law of 1836 provided a dignified procedure, gave the grant a prima facie standing of validity, and
if it did not start this country on its unprecedented if it did not start this country on its unprecedented
industrial era, was at least the most powerful agent in stimulating inventive genius and conserving its fruits. Industrial civilization and invention are inseparable factors. One cannot be comprehended without the other. The present law may , be defertive and the means to administer it may be inadequate, but the fundamental principles upon which it is based are sound It only needs that it be improved in such detail as necessity indicates to make it the effective instrument that Senator Ruggles perceived it to be for the promotion of the comforts, well-being and progress of a civilized state. 
The first commissioner of patents and the man who inaugurated the system under the act of 1836 was Henry L. Ellsworth. During his administration the vulcanization of rubber and the electric telegraph were invented and patented. In the short nine years preceding the 75-year era under discussion such a stimulus was given inventions by the new act as to excite the utmost admiration and wonderment of the Commis sioner as he was about to retire from office. In the birth-year of the Scientific American, the second Commissioner of Patents, Edmund Burke, assumed office, so that the life of this publication is almost coextensive with that of the modern patent system.

A great deal of th? early reports of the Commissioners was devoted to presenting agricultural statistics and information interesting to tillers of the soil. By law, the Commissioner of Patents was charged with this duty. Since that time, this activity became vested in a separate bureau and later in a department, whil the office to which it was originally an appendage is still an obscure subsidiary to an organism to which it has no functional relationship.

\section{The Rush of Patent Business}

Even in the earliest duys of the history of the office, the condition which has since become chronic, manifested itself. In one of his reports, Commissioner Burke complains: "The office is seven or eight months in arrears of its business and is daily becoming more and more embarrassed. Thus, I have in five separate communications to Congress and its appropriate committees within the last two years made full expositions of the embarrassed condition of this office growing out of its greatly increased and increasing business and the ingreatly increased and increasing business and

The fact is that the business presented to the Patent Office has always run ahead of its facilities of per formance. Piblic opinion has failed to recognize the stimulating effect upon invention produced by the patent system and the excessive demands made in turn upon the office by the production of such stimulus. There has been a constant lag between the necessity of giving the office support and the furnishing of the required assistance.

In 1851 , in the annual report of the Commissioner, were published the beginnings of the present Rules of Practice. In that year, also, the reviews of the advances in the arts by the examiners were omitted in the annual reports. These reviews were comprehensive summaries of the inventions patented during the year and were attempts to appraise and analyze the different contributions of the patentees. They indicated much labor and enthusiasm and gave testimony to the extreme regard the examiners must have taken in their pursuits and the wide scope of their interests. in their pursuits and the wide scope of their interests. for patents. Commissioner Hodges commenting upon this showing said: "Some find it difficult to conceive that this flood of discoveries and improvements is still to maintain its progress. They look for a falling of and doubt whether there is room for the continued is room for the continued exEvery step taken, instead of Every step taken, instead of
bringing us nearer to the bringing us nearer to the
close of our career, does but close of our career, does but open new scenes to explore and prepare the way for good prophecy, based upon a thorough consideration of fundamental factors, but rs, but even this bold seer would have hardly dared to imigine an income of applications thirty times as large in the course of

three generations. considerable changes in the consinization of the Patent Office were effected. A perOffice were effected. A perin chief was created to hear in chief was created to hear
appeals taken from the deappeals taken from the de-
cisions of the primary excisions of the primary examiners; the present filing the term of the patent gran was extended to seventeen wears Commissioner Holloyears. Commissioner HolloCivil War, made the pregnant observation in one of nant observation in one of
his annual reports that the introduction of labor-saving devices through the exer-
Before he entered the Patent Office, chaos had descended upon its administration; its procedure was unscientific, unstable and hopelessly involved; its conclusions uncertain and disturbing; while its functions generally were performed inefficiently and with exasperating dilatoriness. Charges were openly made of favoritism in its conduct, while the public could not free itself of suspicions of dishonesty attaching to its methods.

\section{A Critical Period}

He first addressed himself to the task of improving the personnel of the examining corps. As the socalled "American System" of granting patents is bared upon a consideration of the prior art, it is evident that its efficiency is dependent upon the character and qualifications of the men who make the examination. This aspect is the vital factor in the whole theory. Commissioner Fisher sensed its importance at once, and proceeded to introduce a system of selecting appointees which was based solely upon the fitness of the candidates for the designated position. As he stated in his Annual Report for 1869, referring to the qualifications of examiners, "It becomes very important, therefore, to secure competent men for positions of such responsibility. An examiner should be a man of great patience, industry and honesty, of varied and yet thorough mechanical and scientif. attainments, with a good knowledge of patent law, and a mind capable of the nicest discrimination. Though many men offer themselves for the position, but few are fit to fill it."

The tests he constituted were probably the first ever established for entrance into the Civil Service that were rigid, searching and competitive in character. They comprised all the elements of the modern merit system and anticipated its general introduction by al system and anticipated its general introduction by al-
most a generation. It was only through the opposimost a generation. It was only through the opposi-
tion of a public-spirited official now and then who chanced to be in power and who dared to interpose that the logical result did not intervene and disrupt the whole administration of government. One such ofticial was Gov. J. D. Cox, Secretary of the Interior, who had induced Colonel Fisher to accept the Commissionership. The latter knew only too well how important to the industrial interests it was that the work portant to the indice should be conducted by men of technical of the office should be conducted by men of technical
and scientific capacity and of high character. And in his efforts to provide a personnel of the desired at tainments, he was supported without qualification by his immediate superior.

The result of Commissioner Fisher's policy was shown in the character of the new members of the corps, who in all the requirements of the position readily demonstrated a superiority over those in office who had come in under the old order. Secretary of the Interior Cox, who was a powerful barrier to the progress of many a corrupt infiuence and who was most anxious to improve the methods of government administration, gave his testimony of the effect of the new policy in the Patent Office in the following words: "No one could become even superf-
cially acquainted with the cially acquainted with the organization of that impor-
tant bureau without seeing tant bureau without seeing
that a spirit of emulation and real had taken the place of a listless and negligent performance of duty." In reviewing the history of those days, one cannot but help noting how far we have advanced in the ethics of government administration. Those who are despairing of the capabilities and rectitude of the office-holding class have no basis for their pessimism. On the contrary, there is good ground for optimism. A most casual comparison of conditions then and now shows an immense improve ment in the personnel, both in efficiency and honesty, and a decidedly more wholesome atmosphere.

Commissioner Fisher and Secretary Cox were mostly responsible for initiating this movement, which led to this movement, which led to such important resultri in
improving the standards of improving the standards of
public taste and executive

(Continued on page 364) 


\section{W.L. Touglas THE SHOE THAT ma OS TrS ST.00 SHOES FOR MEN AND WOMEN YOU GAN SAVE MONEY BY WEARING W. L. DOUGLAS SHOES}

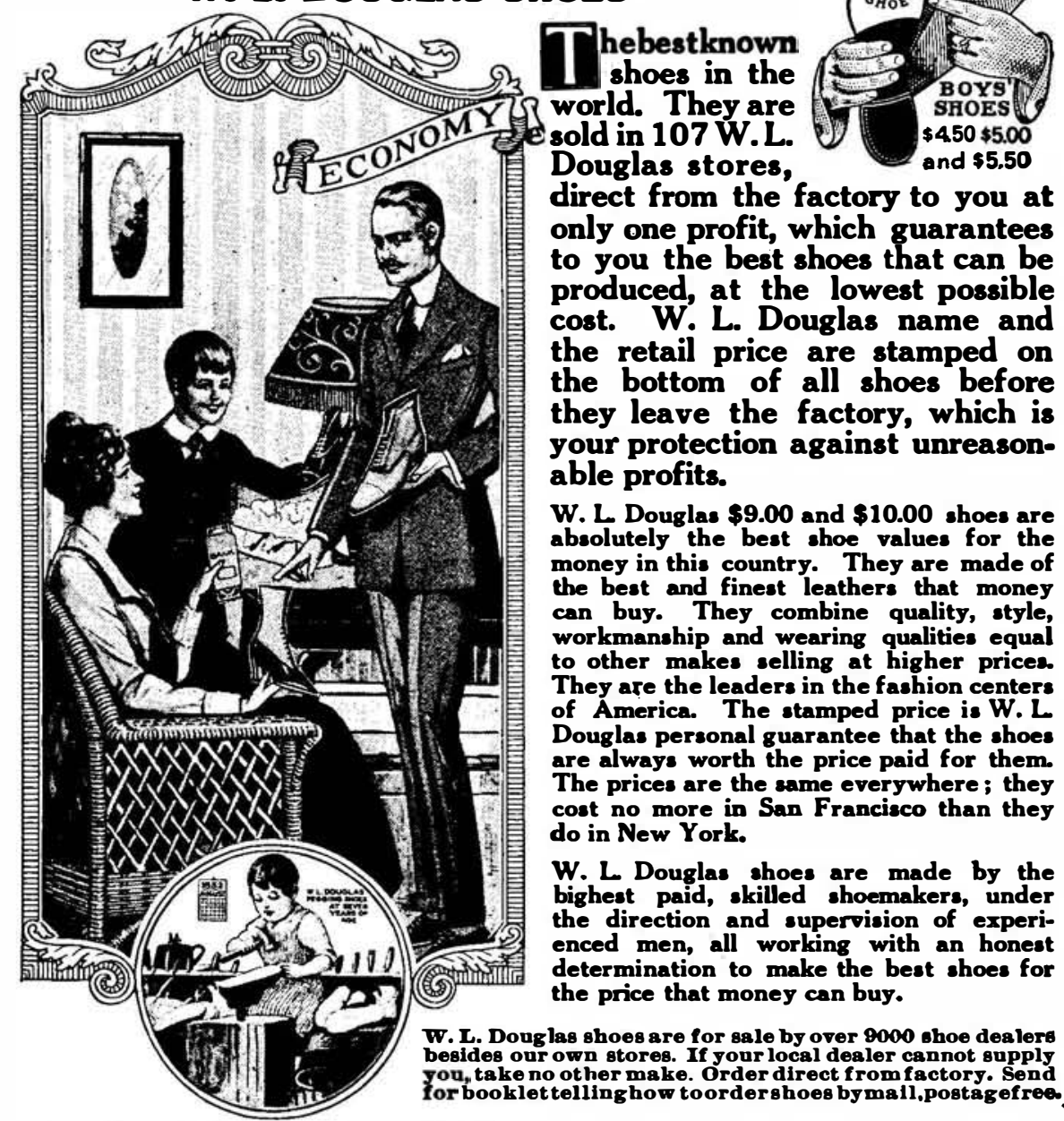

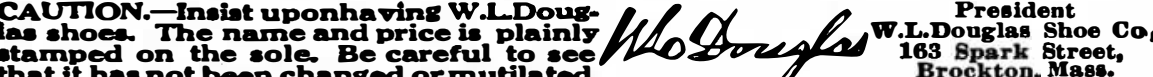

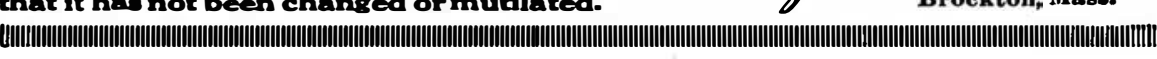

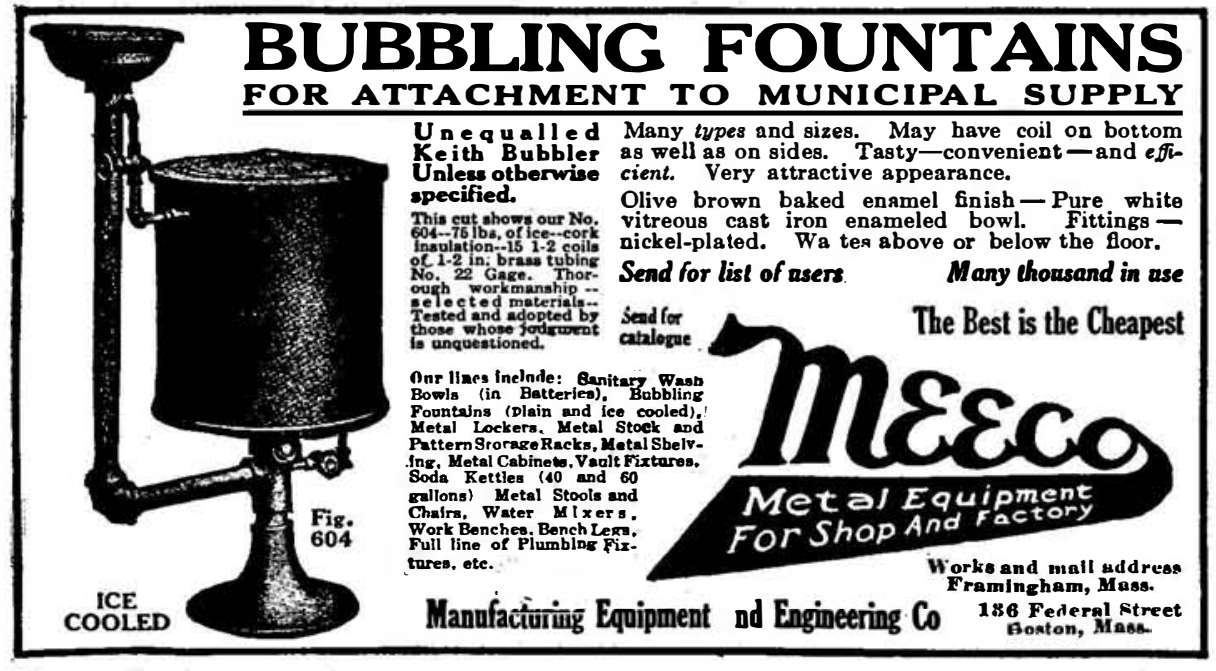

\section{Startling Discovery-}

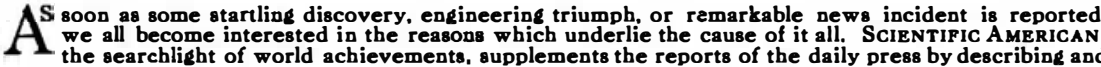
the searchlight of world achievements, supplements the reports of the daily press by describing and
telling accurately, lucidly and graphically, the effect in general it will have on mankind. Fifty-two to you, your business or profession to form a worth-while adjunct to your library and to repay you many
times over the cost of subscription. Send us this coupon and $\$ 1.25$ and we will send you the ScIENTIFIC A MERICAN for the balance of the
year 1920 , commencine with the isue for October 9 , 1920 . The price of 12 copies is $\$ 1.80$. You remit
$\$ 1.25$ on this special offer thereby saving 55 cents.

SCIENTIFIC AMERICAN PUBLSHING CO.

Woolworth Building, New York

Gentlemen: Send me
which 1 enclose \$1.25.

Name

Post Office

8. A. 10.2-20. pearance of the all-metal machine in peaceful pursuits. It was during the last year of the war that German. introduced France, and those Junker monoplanes were erroneously looked upon as mere freaks not worth even copying for experimental purposes. As a result the German air craft constructors have scored a distinct scoop, to use the parlance of the newspaperman, on the world at large. Since the war the Germans have adapted their and as such they have a most excellent sixar eight-passenger machine which has scored many enviable records. The metal airplane, which marks a new era in airplane construction, was predicted in the Scientufic American as early as 1910, together with the retractible chassis, gyroscopic stabilizer, and other features now realized in present machines.

Seventy-five Years of American Patent Administration (Continued from page 341 )

efficiency. It is appropriate that the Patent Office should have been the scene of this innovation, for nowhere else in the Government service is the character of the personnel such a vital factor in the value of its proceedings. If Commissioner Fisher demonstrated nothing eles than the efficiency and morality of the merit system, his administration would have been among the most notable. And yet this was but one of several similarly vital re forms he introduced.

Congressional Recognition

Frequently, an executive's hands are tied by the law. Do all he can, turn as he will, progress may be denied him owing to conditions imposed by statute improve the administration of the office, improve the administration of the office, barred proper development, Commissioner isher next attempted to overcome the inertia of the law-making body. New legislation was absolutely essential for from his experiences, and he did not hesitate to ask for everything that he deemed necessary for that purpose.

In the first place, Mr. Fisher proposed legislation which led to the publication of the Official Gazette and th photolithographing of copies of patents. He was also instrumental in placing on the statute book, with the noweriul aid of Representative Jenckes, the consolidated patent act of 1870 . This act codified the law and, in addition, presented new features tending in the direction of modernization.

The patent act of 1870 not only introduced several broadly new features but codified the laws relating to patents, and the office is now running substantially on the basis of that act. The most imporcreation in $\mathbf{1 8 8 3}$ of the International $\mathrm{Bu}$ reau for the Protection of Industrial Property, by which the residents of every subsidiary country have reciprocal right
in all the other countries in regard to applying for patents and the procedure co nected therewith in the respective paten offices.

The Patent Office and the Courts Another change of momentous influence was the modification of the jurisdiction of the United States Supreme Court. Up to 1891 , the highest court of the land as sumed appellate jurisdiction in patent causes. Since that time, except in highly specialized instances, the courts of last separate circuit courts of appeal. There has resulted from this change, made recessary to relieve the docket of the United States Supreme Court, a confusion of principles, an uncertainty in patent rights and an inconsistency between the frequently inharmonious views of the different but equally important jurisdictions.

\section{PAT E N T S}

IF YOU HAVE AN INVENTION which you wish to patent you can Co. for advice in regard to the best way of obtaining protection. Please send sketches or a model of your invention and a description of
device, explaining its operation.

All communications are strictly confidential. Our vast practice, extending over a period of seventy years,
enables us in many cases to advise enables us in many cases to advise in regard to patentability without Book on Patents is sent free on request. This explains our methods, terms, etc., in regard to Patent SCIENTIFIC AMERICAN

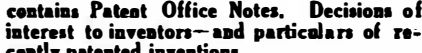

MUNN \& CO., 801101Tons

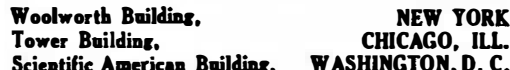
Scientific American Baildings, WASHINGTON, D.C.
Hobart Buildias,

Annual Subscription Rate:

Annual Subscription Rates
Scientific American Publications

Scientific American Publications
Jeac American (established 1845) one

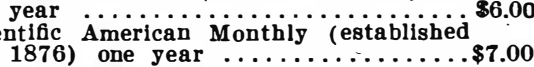
18ge prepaid in United States and posses Foreign Postage
Scientific American \$1.50 per year additional.
Scientific American Montlily $72 \mathrm{2e}$ per year ad-
ditional Canadian Postage
ditionar additional Scientific American 75c per year additional.
Scientific American Mon,thly $36 \mathrm{c}$ per year addiThe combined subscription rates and rates to
foreiga countries, including Canada, will be furnished upon application.
for Remit by postal or express money order, bank Classified Advertisements Advertising in this column is $\$ 1.00$ a line.
No less than four nor more than 12 lines
accepted. Count seven, words to the line. All orders must be accompanied by a remittance.
AGENTS WANTED

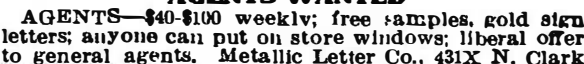
to general agents. Metallic Letter Co.,
Street, Chicago.
ALUMINUM SOLDER ALUMINUM SOLDER
TRY Plerman's "Selmuxing" Aluminum Solder,
guaranteed practical. \$1 per bar, by maill Send cash or
express order. Address A. N. Plerman. i138 Broad St.. express order. Address A. N. Perman, i138 Broad St.
Newark, N. J. BUSINESS OPPORTUNITY
SUBSTANTIAL manufacturing corporation wants SUBSTANTIAL manufacturing corporation wants
capable men to establist branch and manage salesmen.
8300 to 82000 necessary. Will allow expenses to Baltit.
more as explained. Address, Mr. Clemmer, 603 N. more as explained. Address, Mr. Clemmer, $603 \mathrm{~N}$
Eutaw St., Baltimnre. Md.

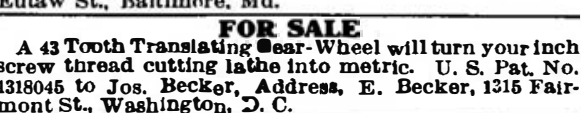
1318045 to Jos. Becker, Address, E. Becker, 1315 Fair
mont St.. Washlngton, D.C.
FOR SAWE U. S. PATENT Burglar and Fire Alarm. It Works
automatically. Connected to doors and windows. When opentat the aiarm soundsat once. Write private. M Mrs.
ootta Thoorblornson, Nadeau, Menominee Co., Michigan MR. INVENTOR: Have you an Idea that you can't
work out? Otet lnt touch with us - we will develop it for clalizing in model and experimental work, developing
and perfecting inventlons. Designers and bullers of
speclaal labor-saving machinery. Els Mfg. Co., 1926B PDeclal labor-saving mack.
Broadway, New York.
PAT BURN FOR SAIE orl BURNER for hot water kettles and wash boller
for outright sale. Reasonable price Canadian rightsas

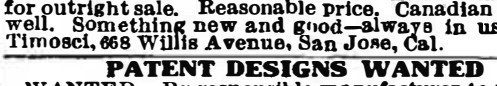
PATENT DESIGNS WANTED
WANTED. By resnonsible manufacturer to purchase
new patented desikns on various toys. Address Box 523. N. Tonawanda, N. Y.

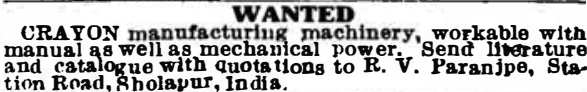
WANTED Wights of some me

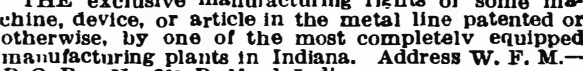
For the Highest Prices ond is false teeth, jewelry, platinum, diamonds, watches, old go!d, sil.
ver, War Bonds and Etamps. Cssh by return mail

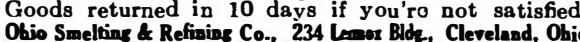
MANUFACTURERS

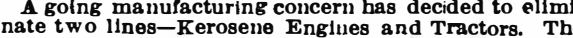

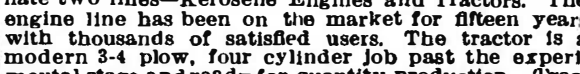
mentsl stage and ready for quantity production. Trac
inga, Patterns, Jlgs. Tools and Parte will be sold easonabler. An exceptiong opporturnity for a manu
acturer to secure two proftable lines. Write, Box 119 , 


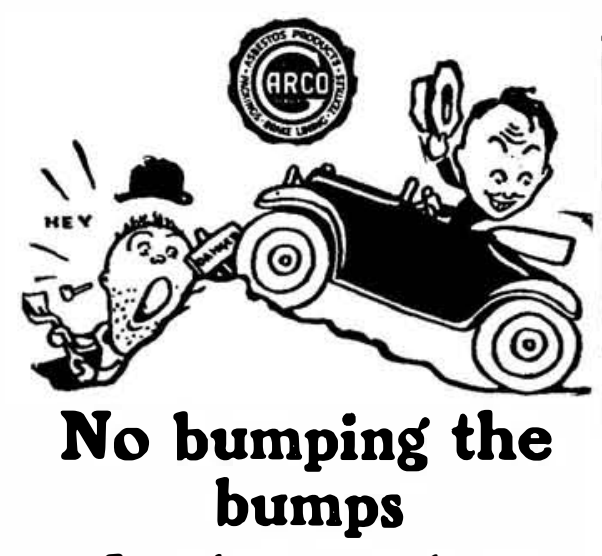

Garco has prevented many men from losing their heads whenconf ronted with emergencies. It'sreliableinaction because it's reliable in construction. It's as tough, durable and gripping as experienced brake lining manufacturers can make it.

Garco is made of the best materials the markets of the world can provide. The more responsible dealers sell Garco.

General Asbestos \& Rubber Co NEW YORK ChICAGO PITISBURG

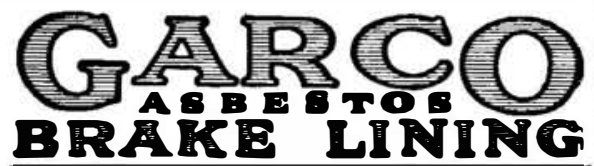

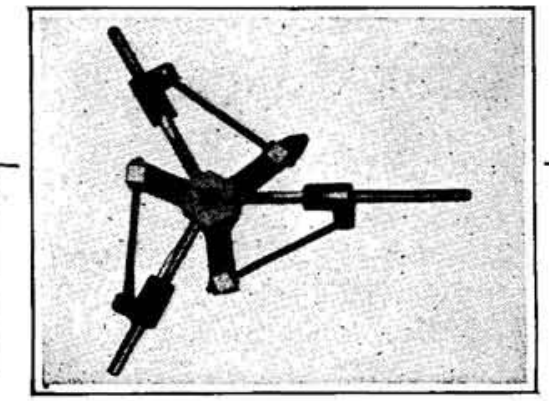

CENTERING TOOL It's a Time Saver

A tool that will give the accurate center of all
cut round stock, shaftings, castings, up to 6 Ensily Operated Jawr Control tho Conter Tool delivered C.O.D. on 10 days' approval.

Write for cinculars Azonts Wantod

Automatic Centering Device Co. Andover

VENTRIOEUSTY Taught Almost Anyone at Rome. Sman cost sonid
today 2-cent stamp for particulargand proof
D. A. SMTH, ROO R695, 801 BIGELOW ST., PEORIA, ILL

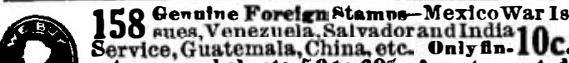

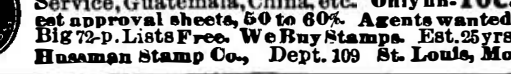

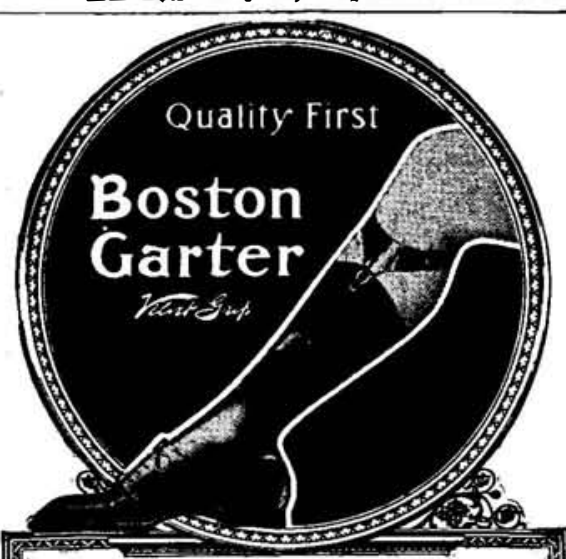

Worn the World Over For more than forty years Boston Garter has been a friend to men the world over.
It not only keeps the old but makes many new ones each year. Most men ask for
Boston Garter as a m a t ter of course GEORGE FROST CO., Makers, BOSTON
But the greatest loss has been in the absence of those great decisions formerly handed down from the Supreme Court bench.

The patent system established by the act of 1836, creating the so-called "American" or "examination" method of granting patents by which scientifically and legally trained men scrutinized the technical merits of the invention, compared it with all known like efforts by an examination of every available printed record and determined the form and legal limitations of the grant, has been pronounced to be the greatest piece of constructive legislation ever placed on our statute books. Certainly, no law designed for purely national aims has ever been copied so extensively as this. Almost every na tion which has any pretension to being infiuenced by modern industrial tendencies, has adopted it or adapted it to its own purposes. This law thrust upon the Patent Office a substantial portion of the legal work that had hitherto devolved upon the courts. It was a radical departure from all existing systems, which merely provided for the "registration" of the application when deposited in the Patent Office, and gave the patent neither legal nor industrial value.

Under the registration system, patents were granted to others than the inventors or for inventions that were old or inop. erative. This system was tried out for 33 years previous to 1836 , and created such uncertainty in the patent situation, opened the door to so many frauds, and was productive of so much unnecessary litigation, that it became more of a menace to industry than a help, and depressed the spirit of invention rather than stimulated it. England, as already stated, discarded this system.

Germany and Japan, the two countries above all others in recent times which have had their eyes open to the main chance, have copied the American or "examination" patent system. No other nations ever made such conscious, deliberate and studied attempts to achieve material success, and they went to every other country to learn what it most had to offer, and did not hesitate to borrow and adopt from it what they found most of value.

Our Patent Growth

America is the land of ingenuity, and the national genius finds its outlet in invention. As far back as 1857 , the applications filed in the U. S. Patent Office exceeded those filed in England by onethird, and since the founding of this government, almost as many patents were granted in the United States as in England, France and Germany combined. The measure of the activity, however, of the Patent Office is indicated by the applications filed, and not by the patents granted. It is curious to observe in this respect how the history of the great war repeats the experience of the Civil War. The heaviest year in applications filed preceding the latter event was in 1860 . In 1861 occurred a decided dropping off, succeeded by gradual gains in the following years. In 1864, with the end of the war in sight, a marked increase took place, while in the three succeeding years the business jumped by leaps and bounds. So in the more recent event-the year 1916 saw the largest business ever presented to the office up to that time. Our entrance into the war did not make itself felt until several months later, but in 1918 its full effect was shown in a 15 per cent drop in receipts from the average of the seven preceding years. Before the year 1919 got well under way, the effect of the cessation of hostilities became apparent, and by summer the receipts be-
gan to exceed those of the heaviest of preceding years.

The intimate association between industrial progress and inventions is shown in the history of two inventions developed during the life-time of the average college boy. The automobile and the moving pic-
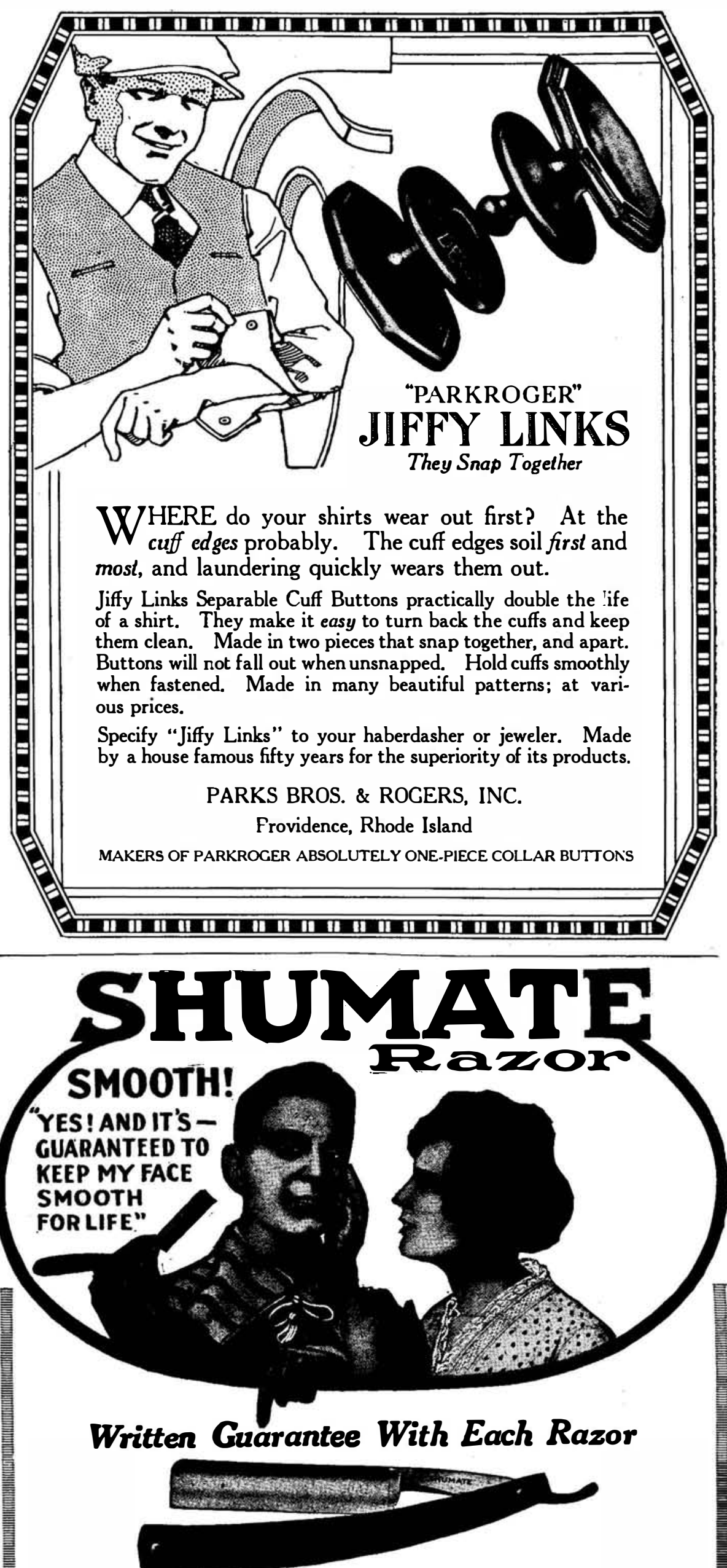

This SHUMATE "Barber" razor is so good that we ganpantoe it to Jou for Zife, Hore's the

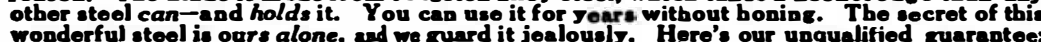

The Shumate Guarantee Buy a SHUMATE "Barbor" Razor an ase it-not once, but as long as you like. don't iko it, wo'll oxchange it without a SHUMATE Razorsaremade by the mastor cutlors of the world, and for more that 33
jears have domonstrated thoir superior
worth to mon who apprecinto roally good rezth to mon who approciate roally good cluding profosesional barbora) aro now uning SHOWATE RRzOR CO. 880 Chestunt St, St. Loris, Mlo.

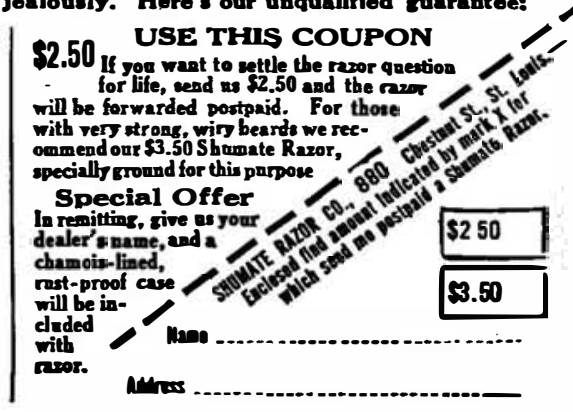



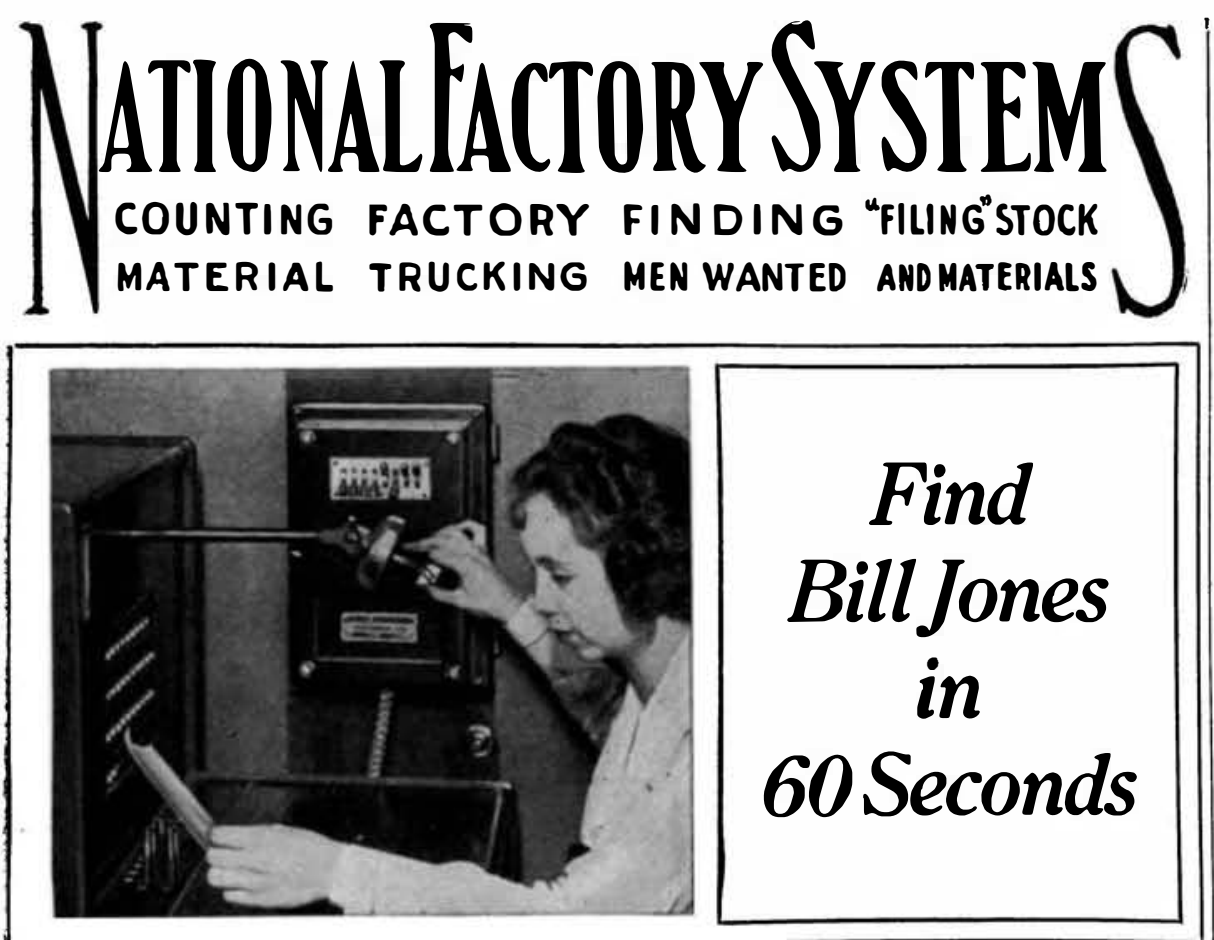

$I_{\text {Jones in } 60 \text { seconds. }}^{\mathrm{T}}$ saves to be able to find Bill business moves along smoothly and quietly. Bill gets his own code call direct from gongs, ica are now equipped with the National Calling horns or buzzers-no one has to waste time in System. We would like to have plant engineers
passing the word along-nor does the telephone and executives know more about it. Bulletin No. operator have to call several departments to find $14 \mathrm{C}$. S. gives a very complete description and on request.

\begin{tabular}{|c|c|c|}
\hline $\begin{array}{c}\text { Counting } \\
\text { MACHINES } \\
\text { FACTORY } \\
\text { LifT-TRUCES }\end{array}$ & $\begin{array}{l}\text { FACTORY-SYSTEMC } \\
\text { NAAIIONAL SCALE COMPANY } \\
\text { 101 Factory Street, Chicopee Falls, Mass. } \\
\text { DEPENDABBLITY }\end{array}$ & 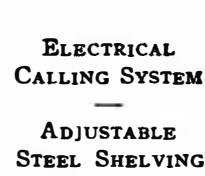 \\
\hline
\end{tabular}

NATIONAL CALLING SYSTEM

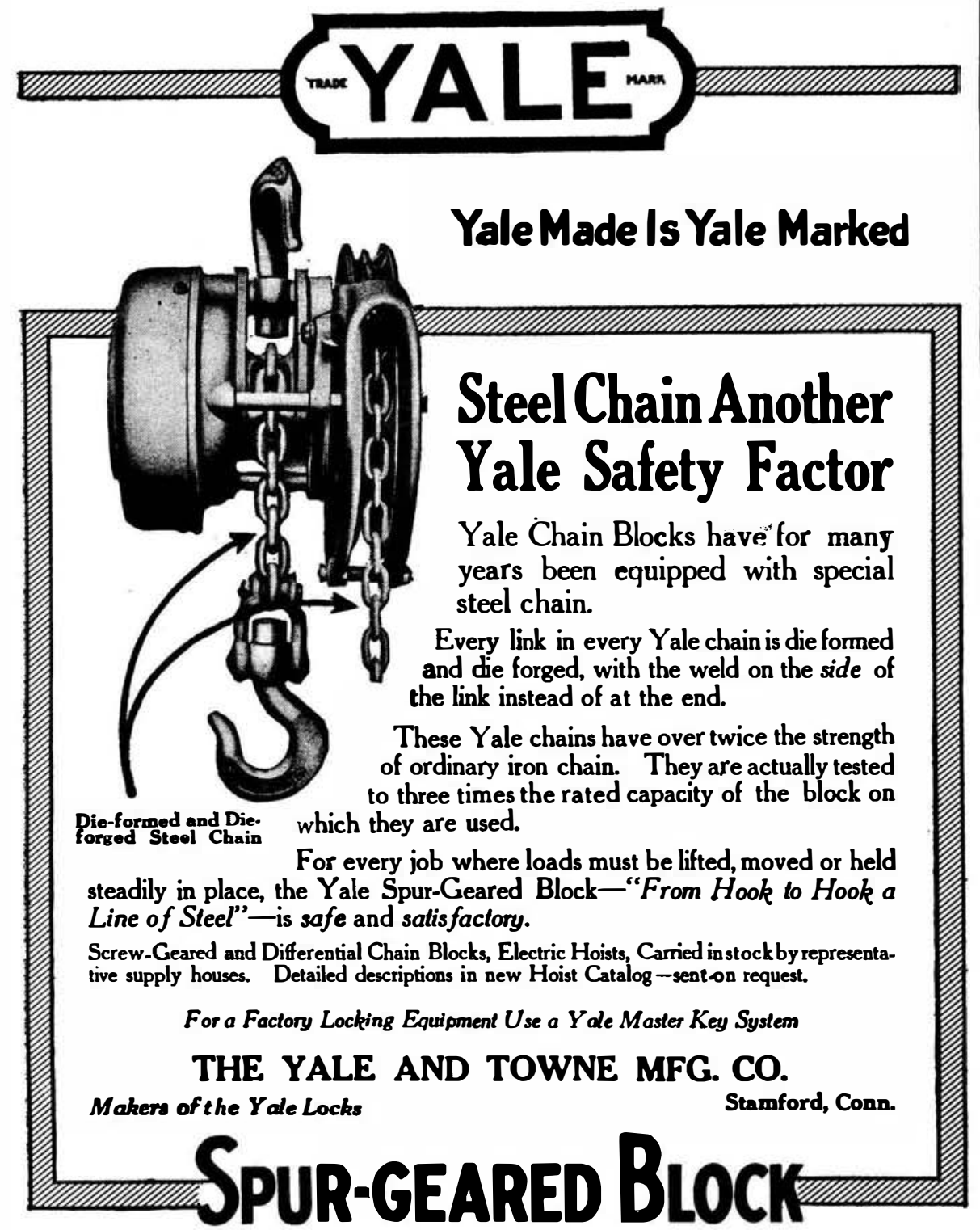

ture were merely experimental features at the beginning of the century. Today,
the film picturizations directly and indirectly involve capital employment going into the billions, while the annual output of automobile and accessory producers aggregates the amazing figure of three and one quarter billions of dollars, which is more than three times as much as the total aggregate of all production in this country in 1850 , when we had a population of 23,191,876. The automobile has jumped Detroit in ten years from a city of the third class to one in the first class, while the "movie" has made Los Angeles a near-metropolis and given it international renown. The difference between countries influenced by invention on the one hand, and removed from its effects on the other is strikingly shown in a United States and Russia.

The Diamond Jubilee of the Scientific American (Continued from page 348) stitution of a carbon paper ribbon. Compliments from our subscribers came from all over the world; for when once in typewritten form there was no difficulty in and printing in the "offset" presses.

The Scientific American Monthly In 1876 the Centennial Exhibition offered such an alluring field with its vast stores of information, that it was decided to publish the Scientific AMERIcan Supplement. When the Exposition closed the SUPPLEMENT was too well liked by the subscribers for the publishers to with the successive volumes until it was decided to bring it out in monthly form beginning January 1,1920 , under the name Scientific American Monthly. In the few months which have elapsed the MonThLY has proved its worth, and is conceded to be the best scient

The Various Homes of the Scientific American

The business homes of Munn \& Co. and the Scievtric have been few in number.

First, 1845-1859, Sun Building, Fulton \& Nassau Sts.

Second, 1859-1882, World Building, 37 Park Row.

Third, 1882-1884, 261 Broadway.

Fourth, 1884-1915, 361 Broadway.

Fifth, 1915 to date, Woolworth Building Messrs Munn \& Co have their own building in Washington, adjacent to the Patent Office, so that the business of their clients can be expeditiously handled. Branch offices are also maintained in Chicago and San Francisco.

It is very seldom in this country that a business enterprise remains in the same family for a period of nearly 75 years It seems appropriate, therefore, to com memorate the event in a becoming manner. The son of one of the original founders is president of the present orFrom Wet Plate to Motion Pictures (Continued from page 346)

when exposed to light in combination with bichromate of potash. This observation was first made by Becquerel. The next idea evolved was that gelatine made insoluble by light might be made to imprison particles of coloring matter. Where light acted, these would remain where it did not act they would wash out by reason of the insolubility of the portion of the films in which they were contained. This was an important step and was made by Poitevin in 1855 . The carbon process now used was invented and patented in 1866 by J. S. Swan.

When the Dry Plates Replaced the Wet Plates

Dry plates were proposed as early as 1854 by Gaudin in France-and Muirhead

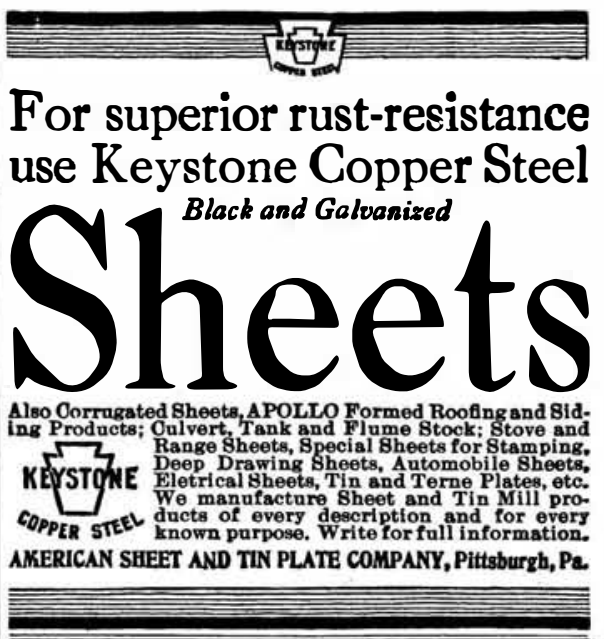

SOUTH BEND LATHES

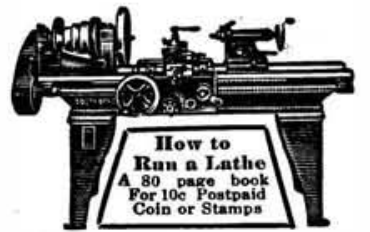

STRAIGHT AND GAP BED

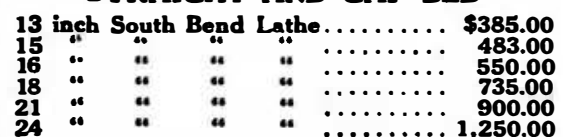
Over 25,000 in use. Est. 1906 Send for Free Catalog SOUTH BEND LATHE WORKS 421 Madison Street South Bend, Ind.

Friction Disk Drill FOR LIGHT WORK

Has These Great Advantages.
The speed can be instantly changed from 0 io 1600
without stopping or shifting belts. Power applied can

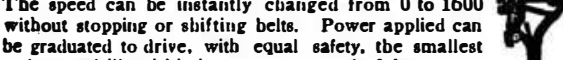
or largest drills wittin its range- a wolderfu
in time and great saving in drill breakage. Send for Drill Catalogue

W. F. \& Jno. Barnes Company 1999 Ruby Street 1872 G E A R S S We Will Make It dured from any Inetal and finished in any colur.
Waterbury Button Co., Waterbury, Conn. A MACHINESI Corliss Engines, Brewers G5 and Bottlers' Machinery 899 Clinton Street VILTER MFG. CO. UNISOL BOILER PRESERVER

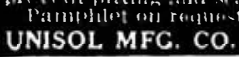

Experimental and Model Work Fine Instruments and Fine Machiners,

Apecial Twole, Dlea, Gear atting, Ete.
HENRY ZUHR, 489-93 Broome St., New York City

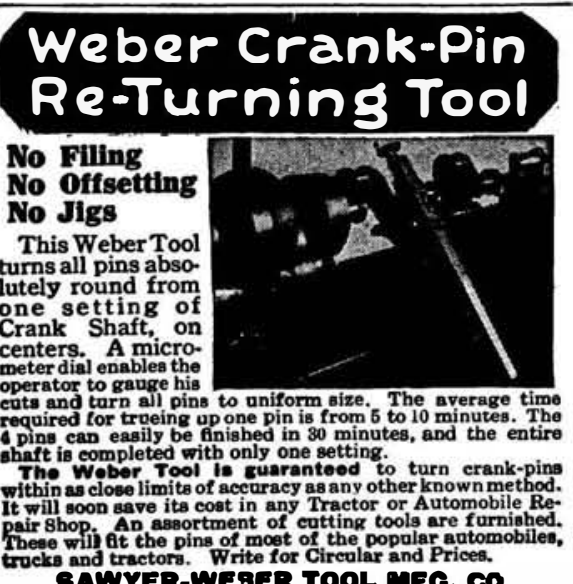

BAW tractors. Write for Circular and Prices.
SAWYER-WEBER TOOL MFG. CO. 